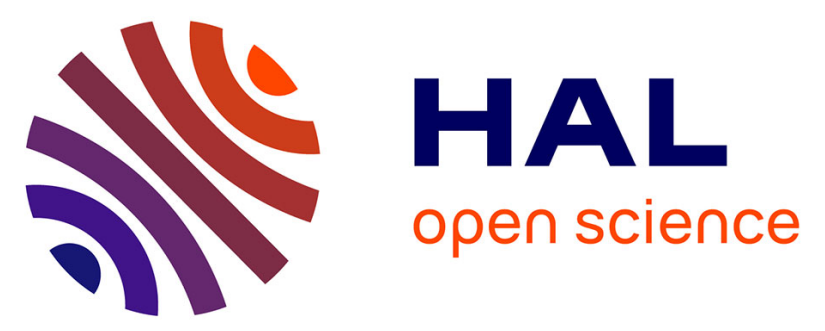

\title{
Exposure source for skin sensitizing hydroperoxides of limonene and linalool remains elusive: an analytical market surveillance
}

\author{
Andreas Natsch, Marco Nägelin, Hans Leijs, Michel van Strien, Elena \\ Giménez-Arnau, Matthias Vey, Cécile Gonzalez
}

\section{To cite this version:}

Andreas Natsch, Marco Nägelin, Hans Leijs, Michel van Strien, Elena Giménez-Arnau, et al.. Exposure source for skin sensitizing hydroperoxides of limonene and linalool remains elusive: an analytical market surveillance. Food and Chemical Toxicology, 2019, 127, pp.156-162. 10.1016/j.fct.2019.03.028 . hal-02330658

\section{HAL Id: hal-02330658 \\ https://hal.science/hal-02330658}

Submitted on 24 Oct 2019

HAL is a multi-disciplinary open access archive for the deposit and dissemination of scientific research documents, whether they are published or not. The documents may come from teaching and research institutions in France or abroad, or from public or private research centers.
L'archive ouverte pluridisciplinaire HAL, est destinée au dépôt et à la diffusion de documents scientifiques de niveau recherche, publiés ou non, émanant des établissements d'enseignement et de recherche français ou étrangers, des laboratoires publics ou privés. 


\section{Exposure source for skin sensitizing hydroperoxides of limonene and linalool remains elusive: an analytical market surveillance}

Andreas Natsch ${ }^{1}$, Marco Nägelin ${ }^{2}$, Hans Leijs ${ }^{3}$, Michel van Strien ${ }^{3}$, Elena Giménez-Arnau ${ }^{4}$, Matthias Vey ${ }^{5}$ and Cecile González ${ }^{5}$

1 Givaudan Schweiz AG, In Vitro Molecular Screening and Analytical Chemistry, Ueberlandstrasse 138, CH-8600 Duebendorf, Switzerland

${ }^{2}$ Solvias AG, Römerpark 2, Kaiseraugst, Switzerland

${ }^{3}$ International Flavors \& Fragrances, Zevenheuvelenweg 60, 5048 AN Tilburg, Netherlands

${ }^{4}$ Université de Strasbourg, Institut de Chimie, CNRS UMR 7177, 4 Rue Blaise Pascal, 67081

Strasbourg, France

${ }^{5}$ International Fragrance Association, Avenue des Arts 6, 1210 Brussels, Belgium

* Corresponding author, andreas.natsch@givaudan.com

\section{Keywords:}

Terpene hydroperoxides, skin allergy, quantification, consumer products, market surveillance

Running head: hydroperoxide quantification in consumer products 


\begin{abstract}
Reports about positive patch test reactions to oxidized linalool and limonene remain frequent. These terpenes are fragrance ingredients widely present in consumer products. The main sensitizing ingredients in the oxidation mixtures of these terpenes are hydroperoxides (HP). Currently, it is not clear whether fragranced consumer products are a relevant exposure source for HP. Analytical methodologies had been developed and validated in blind-coded ring-trials in multiple laboratories allowing quantification of the HP in different consumer products. The analytical approach had been successfully transferred to an independent third party laboratory and was now used in the analytical investigation of consumer products. In total, 104 products were analysed with a method based on hydroperoxide reduction followed by GC-MS. Samples included aged and new samples from the same brand, products which were suspected by patch test positive patients to elicit their symptoms and some products containing high levels of essential oils. Only four samples contained $>50 \mu \mathrm{g} / \mathrm{g}$ of at least one of four analysed HP by the reduction method. Confirmatory analysis by LC-MS methods directly testing for presence of the hydroperoxide indicated that levels are even below those observed by the conservative reduction method. The samples retrieved from patch-test positive samples were below detection limit for all four target analytes by GC-MS, and LC analysis with three methods confirmed this negative result. This independent market surveillance indicates that concentrations of HP in investigated consumer products and patient products are orders of magnitude below reported sensitizing or elicitating doses. No evidence for hydroperoxide accumulation in aged products or products used by patients could be found. The nature and source of the inducing agent responsible for the frequent positive patch test reactions to oxidized terpenes remains elusive.
\end{abstract}




\section{Introduction}

Linalool and/ or limonene are present in the majority of leave-on cosmetic products ${ }^{1}$. Both linalool and limonene are non-sensitizing according to data from most human and guinea pig studies $^{2}$, and they are only very weak sensitizers according to the local lymph node assay performed in mice ${ }^{3}$. Despite their widespread use, positive patch test reactions for linalool and limonene are only rarely reported from the dermatological clinics ${ }^{4,5}$, confirming the low sensitization potential. However, neat linalool and limonene were shown to undergo autoxidation when agitated for prolonged periods of time in the presence of air. ${ }^{6-11}$ The airoxidized terpenes were found to be skin sensitizing in animal tests. Within the complex autoxidation mixtures, hydroperoxides (HP) were identified as the key allergens ${ }^{12-15}$.

Oxidized samples of both limonene and linalool are commercially available to dermatologists to perform patch tests in order to identify possible causes of allergic contact dermatitis. ${ }^{13,16,17}$ So far, these autoxidation mixtures have been tested on a cumulative number of $>22^{\prime} 000$ patients ${ }^{16-}$ 22. These studies reported high frequencies of positive reactions to the two oxidized terpene preparations. In general more frequent reactions are reported to oxidized linalool, which is tested at a higher concentration than oxidized limonene. Thus on the average $4-6 \%$ of tested patients respond to oxidized linalool, and similar or even higher frequencies of doubtful or irritant reactions were reported in parallel ${ }^{16,17,22}$.

It was often inferred from these studies that the HP formed from limonene and linalool are among the most common causes of contact allergy ${ }^{13}$ and a causal link between these frequent reactions and widespread exposure of consumers to parent linalool and limonene from consumer products was made ${ }^{23}$. However, in order to scientifically substantiate this link one would have to prove that the parent molecules oxidize in the consumer products or that partly oxidized raw materials are used in product manufacture resulting in sufficiently high HP levels in the products to trigger active sensitization of a large number of consumers. Thus, to establish relevance of the positive patch-test reactions reported from the dermatological clinics, quantitative determination of the HP in consumer products on the market in general and more specifically in products used by the patients would be required.

Reliable analytical methods to determine HP levels in consumer products have been developed in recent years and they were compared and evaluated in detailed studies within the IDEA project (International Dialogue for the Evaluation of Allergens) involving stakeholders from academia, industry and the dermatological community ${ }^{24}$. IDEA was launched by the fragrance industry in collaboration with the European Union to address open questions on contact allergy to fragranced products following the opinion of the European Union's Scientific Committee on Consumer Safety (SCCS) on fragrance allergens ${ }^{25}$.

A simple method with a reduction step using triphenylphosphine $\left(\mathrm{PPh}_{3}\right)$, followed by GC-MS to detect alcohols formed by HP reduction ${ }^{26}$ was evaluated in two blind-coded method evaluation studies on fine fragrances ${ }^{27}$ and creams and lotions ${ }^{28}$. Accurate quantification of spiked hydroperoxides in the different products by this method was shown. This method has the 
drawback that it may lead to an overestimation of the true content of HP if the alcohols formed by HP reduction are already present as fragrance ingredients and it is therefore a conservative method. On the other hand it avoids any potential issues due to instability of HP during sample preparation and extraction.

In parallel, these method evaluation studies also tested the same blind-coded samples with several liquid-chromatography (LC) based methods directly detecting the parent hydroperoxide. These included a HPLC-chemiluminescence (HPLC-CL) method ${ }^{29}$, an LC-Q-TOF-MS method and an LC-orbitrap-MS method ${ }^{30}$. As a general recommendation, it was concluded to use the robust GC-MS reduction method for a screening approach and to validate the result for each sample with a standard addition experiment, while the LC-based methods could then be used for verification of presence of parent HP in positive samples ${ }^{27,28}$ in specific cases.

Here, we collected different used products from consumers and new products from the general market covering a wide range of product types and with linalool or limonene declared on the label. Emphasis was given to include old and fresh samples from the same brand, products from patients tested positively for the oxidation mixtures and products containing essential oils, in order to test different possible exposure sources. All samples were analysed by the GC-MS reduction method, and confirmatory analysis on a subset of samples was made with LC-MS.

\section{Materials and Methods}

Analytical reference standards. HP reference standards (linalool-7-OOH, linalool-6-OOH, limonene-1-OOH and limonene-2-OOH) were prepared by GreenPharma (Orléans, France) as described before ${ }^{27}$. Fresh samples with a purity of $>98 \%$ were prepared for this study. These standards were also used for the standard addition experiments (see below).

\section{Analytical methods}

Reduction of terpene HP with triphenylphosphine $\left(\mathrm{PPh}_{3}\right)$ to form specific alcohols is possible in different consumer product matrices ${ }^{27,28}$. This transforms the hydroperoxides into an easily measurable stable analyte, which is then measured by GC-MS. Thus the four HP in oxidized linalool and limonene are linalool-7-OOH, linalool-6-OOH, limonene-1-OOH and limonene-2$\mathrm{OOH}$, and they are reduced to linalool-7-OH, linalool-6-OH, limonene-1-OH and limonene-2$\mathrm{OH}$ (carveol), which are the 'target analytes' investigated here. A standard operation procedure for this method was published along with our previous publication ${ }^{28}$ and was followed for analysis of all products in this study. It includes two different sample preparation methods for alcoholic fine fragrances and for complex products containing water (creams, lotions, etc.). Calibration was done based on external calibration curves with the four synthetic HP standards treated with the reduction method under identical conditions. To ensure successful detection of the HP by this method in the different product matrices, each sample was analyzed as received and as a parallel sample with a standard addition adding a final level of $50 \mu \mathrm{g} / \mathrm{g}$ of each of the 
four HP to the test sample. For this method we defined a 'reporting limit' of $50 \mu \mathrm{g} / \mathrm{ml}^{28}$, i.e. a level at which the alcohol from the reduced HP can be accurately measured in different product types, as it is not practicable to determine the true limit of quantification (LOQ) in each product matrix. The standard addition experiment was set to $50 \mu \mathrm{g} / \mathrm{g}$ to reflect this reporting limit, and it allows checking successful detection of this specified level in each different product matrix investigated. However, here also levels below this reporting limit are indicated for full transparency, but these must be viewed with some caution.

LC-Chemiluminescence measurements, LC-Q-TOF-MS and LC-orbitrap-MS measurements were performed with the methods also previously described in detail ${ }^{28}$.

\section{Procedure for collection consumer products}

IDEA Management Team (IDEA MT) organized the collection of samples and the shipment to the analytical laboratory (Solvias, Kaiseraugst). Samples were directly collected by the team or provided by members of the IDEA hydroperoxides taskforce. In general, partly used products donated by consumers were collected and they were matched with fresh products of the same brands bought on the market to be able to determine influence of product storage. As inclusion criteria, products should have a declared linalool and/or limonene content and batch number /production code to ensure traceability. In addition, samples donated by dermatological patients were included (esp. those tested positive for the terpene oxidation mixtures) and were suspected by them to be involved in their clinical reactions (samples furnished by the Spanish Contact Dermatitis Group GEIDAC). All samples provided by the dermatological centres were tested, even if no matched fresh product could be sourced or if no linalool or limonene content was declared. Five additional fresh consumer product samples were selected, which contained essential oils as declared by the product labelling, since some samples of essential oils were reported to contain high levels of HP ${ }^{31}$. Tested products also included two commercial fine fragrances provided by a manufacturer with different aging: (i) as fresh samples, (ii) as longtime stored samples and (iii) as artificially aged samples.

Finally, one sample of an aftershave was received from the University of Stockholm. This sample had recently been found to contain a significant level of linalool-6-OOH by a new twodimensional LC-MS method ${ }^{32}$, and it was reanalysed by the four different methods from our method evaluation and validation studies to link our investigations with those published data on the same sample. However, this sample does not form part of the 'random' sample collection, as it was selected from a larger number of random samples based on a previous analytical result. All the samples above were analysed with the GC-MS-reduction method. Five positive samples above the reporting limit defined earlier and a matched fresh sample were re-analysed by three LC-MS based methods to further evaluate the positive results in the screening. In addition, 11 samples recovered from patch test positive patients were re-analysed by LC-methods to confirm the negative results obtained.

Finally, content of non-oxidized linalool and limonene was analysed semi-quantitatively based on the GC-MS results in all products. However, this was not a primary goal and the method was not optimized for the analysis of these analytes (a different dilution would be selected to 
quantitatively analyse these much more abundant analytes if that would be the primary goal, but primary goal was to be highly sensitive for the alcohols formed by HP reduction).

\section{Results}

All results on the individual analysed samples are provided as an excel-file in supplementary information, and data are sorted into sheets in the order they are discussed here.

We collected 31 used samples from diverse product types, which we could match with samples of freshly purchased products. This set of samples forms the majority of analysed products. They all had a declared content of linalool or limonene, and with four exceptions both terpenes were labelled on these products. Only one of these 31 aged samples and none of the fresh samples contained one of the target analytes above the reporting level: $91 \mu \mathrm{g} / \mathrm{ml}$ of limonene-1-OH was detected in an Eau de Toilette, while $45 \mu \mathrm{g} / \mathrm{ml}$ of this analyte was detected in the matched fresh product. This product (Sample A in Table 1) contained $>5000 \mu \mathrm{g} / \mathrm{ml}$ of parent limonene according to the semi-quantitative analysis. Re-analysis by three LC-based methods overall confirmed the result of GC-MS reduction method and could identify this HP in the range of $30-$ $100 \mu \mathrm{g} / \mathrm{ml}$ in the aged and $8-38 \mu \mathrm{g} / \mathrm{ml}$ in the fresh sample (Table 1). Overall, analysis of this dataset indicated no widespread oxidation of the two terpenes between product manufacturing and the time the aged products were sampled. Compared to the high level of parent linalool and limonene, HP are either very minor constituents or are not detectable at all in these products.

A further set of samples comprises 20 aged samples from consumers, for which no matched fresh sample could be found on the market. A body oil (sample B) contained $69 \mu \mathrm{g} / \mathrm{ml}$ of limonene-2-OH, while semiquantitative analysis found $710 \mu \mathrm{g} / \mathrm{ml}$ of parent limonene. LCanalysis by three different methods could not detect the parent HP limonene-2-OOH, while the standard addition indicated high reliability.

A set of 10 samples collected by dermatologists from patients had neither limonene nor linalool content declared. Correct declaration could be confirmed by analysis for parent linalool and limonene, which were absent in these samples, and, not surprisingly, also no indication for hydroperoxide content was found in this set of samples.

From the three sample sets described above, a subset had been collected by dermatologists from their patients as these products were suspected to elicit their reactions. This subset is separately summarized in a further data sheet in the supplementary file. Eleven samples were from patients, which are positive to at least one of the oxidized linalool or limonene. For the patients donating the other samples the patch test to the oxidation mixtures was either negative or not performed. In none of the 28 samples collected from patients, could we detect by the GC-MS method any of the four target analytes above $50 \mu \mathrm{g} / \mathrm{ml}$ (except linalool-7-OH in one sample at $38 \mu \mathrm{g} / \mathrm{ml}$, all were $<22 \mu \mathrm{g} / \mathrm{ml}$ for all four analytes). Furthermore, absence of the hydroperoxides above reporting limit was confirmed in the 11 samples from patch test positive patients by both LC-MS methods. Also the LC-Chemiluminescence found only traces in two samples (Table 2). 
As some literature data indicate rapid accumulation of hydroperoxides in essential oils ${ }^{31}$, five additional products were purchased which have a declared content of essential oils and declared linalool / limonene content. Two of these samples (Sample C and D in Table 1) contained at least one of the target alcohols above the reporting limit when analysed by the GC-MS-reduction method. However, re-analysis by LC-MS could not confirm the presence of parent HP. Here it has to be kept in mind that the reduction method can lead to an overestimation if the reduced alcohol is already present in the product. The shower oil sample D was thus analysed in some more detail. Based on the declaration, this sample contains a multitude of essential oils containing linalool and limonene (different citrus and orange oils, different lavender oils). Since the content of both limonene and linalool was outside of the calibration range, dilutions of the product were re-analysed. It was found that this product contains $215^{\prime} 000 \mu \mathrm{g} / \mathrm{ml}$ and $143^{\prime} 000$ $\mu \mathrm{g} / \mathrm{ml}$ of limonene and linalool $(21.5 \%$ and $14.3 \%$ of the total product). Hence, presence of low levels of the alcohols limonene-1-OH and limonene-2-OH, which can be found in citrus oils, is not completely surprising (Table 1). Interestingly, LC-methods found no indication of significant hydroperoxide content in this product with highly exaggerated content of essential oils.

We also analysed two commercial fine fragrances obtained from the manufacturer as a (i) fresh sample, (ii) an artificially aged sample ( 3 months at $\left.45^{\circ} \mathrm{C}\right)$ and a (iii) sample stored at room temperature for 3 or 6 years. As indicated in Table 3, all samples were below reporting limit of $50 \mu \mathrm{g} / \mathrm{ml}$ for all four analytes, but above detection limit for some of the analytes. The data in Table 3 indicate no accumulation of the target analytes, nor degradation of the parent linalool or limonene under the storage conditions.

We did complete this study by analysing an aftershave sample, which was received from the University of Stockholm. It had previously been analyzed by a novel heart-cut 2D LC-MS method ${ }^{32}$. This sample (labelled Sample 6 in the publication; aged $>5$ years) was selected as it contained the highest HP level from a series of market products by this previous analysis and the highest ever reported terpene HP concentration in a commercial sample, i.e. it was reported to contain $420 \mu \mathrm{g} / \mathrm{ml}$ linalool-6-OOH and ca. $20 \mu \mathrm{g} / \mathrm{ml}$ linalool-7-OOH by that novel method. It was reanalysed with the toolbox of methods used here. While $81 \mu \mathrm{g} / \mathrm{ml}$ of the alcohol linalool-6$\mathrm{OH}$ could be detected by the reduction method, LC-MS found no detectable level $(<25 \mu \mathrm{g} / \mathrm{ml}$, LC-Orbitrap), or $7 \mu \mathrm{g} / \mathrm{ml}$ (LC-Q-TOF) or $4.6 \mu \mathrm{g} / \mathrm{ml}$ (LC-CL) of the parent HP Linalool-6-OOH (see supporting Information). Analysis by these multiple techniques and detection modes indicates that the HP level is much lower as compared to the published value.

As many negative results are reported here, especially also in the screening with the conservative reduction method, it is important that these results are validated and that potential hydroperoxides are not masked by interference with product matrix. Hence the standard addition experiments are of particular importance to prove that added hydroperoxides are successfully detected. The individual results of the standard addition experiments are all reported in the tables in the supporting information. For each of the four target hydroperoxides, the recovery in $\%$ is indicated for each product. From 4 (n HP) $\times 104$ (n samples) $=416$ datapoints, only in one case 
the added standard could not be detected due to interference. In $88 \%$ of the cases, the recovery was $>70 \%$, Figure 1 shows the box plots for the recovery from all samples.

\section{Discussion}

This study analysed a broad variety of consumer products containing linalool and/or limonene. Based on the conservative GC-MS-reduction method, 99 of the 103 products $(96 \%)$ contained hydroperoxides below the reporting level, while 102/103 (99\%) contained less than $100 \mathrm{ppm}$. Re-analysis by LC-MS indicated that these data are still an overestimation, as only in one sample the hydroperoxide level determined by the GC-MS method could be confirmed, while esp. the essential oil containing products probably appeared not to contain the hydroperoxide but the reduced alcohol. Overall, these data indicate that hydroperoxides of linalool and limonene are not extensively present in consumer products.

Analytical confidence. From an analytical standpoint the overestimation observed in few samples containing essential oils by the GC-MS-reduction method may be criticized. The possibility for some overestimation due to presence of reduced alcohols was known from the beginning and it

was discussed before ${ }^{26,27}$, however it does not significantly affect the overall conclusion, namely the low frequency of positive samples and low levels in those samples above the reporting limit. More important is the positive predictivity, i.e. that samples containing hydroperoxides can be reliably identified. Thus the standard addition experiments indicated that positive detection of the standard addition was successful in 415 out of 416 individual HP determinations, proving successful positive detection. Moreover, in the 11 samples obtained from patients positive for the oxidized terpenes, absence of significant HP levels as determined by the GC-MS reduction method was confirmed by three independent LC-based methods. Thus all the data on lack of significant HP-presence in the investigated samples can be considered to be highly reliable based on the detailed control experiments performed here.

The exact quantification of low levels of course is more challenging, as can be seen form the results of the different LC-methods with some variability between methods observed for sample A. In addition, recovery of the standard addition was below $70 \%$ in several samples in the GCMS method. While, from an analytical standpoint, this is not completely satisfactory, confidence in negative results and quantitative accuracy in the correct order of magnitude is largely sufficient for the toxicological assessment, see below discussion on the known, toxicologically relevant doses.

Comparison to previous data. Previous studies on hydroperoxide levels in consumer products focused on fine fragrances and deodorants ${ }^{26,30}$. Those studies were conducted before the methods were validated in the blind-coded ring trial and did not include complex products like creams and lotions. Nevertheless, the overall conclusions are congruent with the current data. In 39 aged fine fragrance samples from consumers, only 14 contained limonene-2-OOH as determined by the reduction method and levels were below $5 \mu \mathrm{g} / \mathrm{ml}^{26}$. In 22 of these 39 samples, linalool-OOH was detected with a geometric mean of $30 \mu \mathrm{g} / \mathrm{ml}$ as determined by LC-MS ${ }^{30}$. Only one sample 
contained $>100 \mu \mathrm{g} / \mathrm{ml}$. In a set of 10 products recently analysed by the novel two-dimensional LC-MS method ${ }^{32}$, linalool-OOH levels were in the same range, only one sample contained significantly higher hydroperoxide level of the isomer linalool-6-OOH, which normally is the minor isomer in oxidized samples. However, this analytical result could not be reproduced with the methods used here applied to the same sample (See supplementary information for detail). Thus this broad market surveillance aligns well with smaller studies performed before.

Importance of product type. In terms of product types being at highest risk to contain HP, fine fragrances would be suspected first, as they contain the highest fragrance levels. Here we could positively identify limonene-1-OOH in one eau de toilette and, as indicated above, linalool-OOH could be identified in fine fragrances before. In addition we could identify the target alcohols in three body oils and shower oils based on the reduction method, however in these three cases HP levels were not confirmed by the LC-methods and these oils probably contained low levels of the alcohols which are naturally present in essential oils used for manufacture. This explanation is particularly likely for sample C. As it contained a cumulative amount of $36^{\prime} 000 \mu \mathrm{g} / \mathrm{g}$ of linalool and limonene from natural oils, presence of a cumulative amount of $400 \mu \mathrm{g} / \mathrm{g}$ of the reduced alcohols (i.e. 1\% compared to the linalool and limonene content) is not surprising. We could not detect HP in any of the creams and lotions tested, despite the fact that our method was specifically developed and validated for that purpose ${ }^{28}$.

Effect of product age. In principle, commercial products could be clean in the beginning and then accumulate HP upon aging. Here we analysed old and new products and there was no evidence of HP formation upon product aging, this can nicely be seen in the two products shown in Table 3 but also by the overall results of the 31 products analysed fresh and aged. Only in sample A the level of limonene-1-OOH was indeed higher in the aged product, but only by a factor of two, and this could in principle also be due to a batch effect, as the aged product was produced at a different time.

In theory, HP could also form over time and disappear again. However, if oxidation would progress significantly over time, we would expect lower levels of linalool and limonene in old products. Here only tentative conclusions can be made, as analysis of parent linalool and limonene was only semi-quantitative. Nevertheless, on the average, aged samples contain 95\% of the limonene and $99 \%$ of the linalool content of the fresh samples. Similarly, the two fragrances with controlled aging in Table 3 contain stable levels of the parent molecules even when aged up to six years. This is in accordance with controlled stability studies over 9 months with accelerated aging of linalool in an eau de toilette matrix, where no significant degradation was observed even in half-filled, repeatedly opened bottles incubated at $45^{\circ} \mathrm{C}^{30}$.

Products retrieved from patients. A key new aspect of our study is inclusion of samples from patients that were patch test positive to linalool ox. and / or limonenen ox. No target alcohols could be detected in any of those products ( $<22 \mathrm{ppm}$ for all four hydroperoxides) and 50-100\% recovery of standard addition in those samples indicates that lack of HP detection cannot be attributed to analytical failure. Re-analysis by LC-MS methods confirmed these negative results. 
Thus, exposure to these particular product samples can neither explain the positive patch test reactions, nor an elicitation due to HP contained therein.

$H P$ content and analytical sensitivities compared to toxicological data. The analytical sensitivities and the detected levels should always be compared to the concentrations of toxicological concern based on the available data from animal and human studies. Thus the dose per area triggering an EC3 in the local lymph node in mice is at 16'000 $\mu \mathrm{g} / \mathrm{g}$ for linalool-OOH and 3300 and $8300 \mu \mathrm{g} / \mathrm{g}$ for the two limonene isomers. The concentration used for induction in guinea pig tests was $15^{\prime} 000 \mu \mathrm{g} / \mathrm{g}$ for the limonene hydroperoxide fraction ${ }^{15}$. Patch test preparations used in the clinics contain 3300 (limonene-OOH) or 10'000 (linalool-OOH) $\mu \mathrm{g} / \mathrm{g}$ of the HP. Compared to these figures, the analytical sensitivities of the methods used here are much lower, thus we cannot attribute a widespread sensitization as stipulated by the high patch test frequencies to possible undetectable levels escaping our analytical sensitivities. A comparison of the exposure based on the analytical data with the exposure in the predictive and diagnostic human and animal tests was made in detail before for linalool hydroperoxides (Table $6 \mathrm{in}^{30}$ ). It was concluded that between levels in consumer products and known sensitizing doses there is a factor of at least three orders of magnitude. A similar assessment is made here in Table 4 for limonene-1-OOH, which was confirmed to be present in one fine fragrance sample in this study. Based on the results from the current study, the previous assessment remains unchanged, as the consumer exposure from the single positive sample under application conditions of fine fragrance is three orders of magnitude lower as compared to the dose used in a diagnostic study ${ }^{33}$. Also the defined reporting limit is 300 -fold below the routine patch test concentration.

\section{Conclusions}

This study and previous studies come to congruent results: we cannot find, by analytical means, evidence of presence of hydroperoxides which can be linked to reported thresholds for sensitization in consumer products from the general market, nor in aged samples retrieved from consumers or patients. There is a wide gap between the analytical sensitivity (for negative samples) and the reported levels for the positive samples and the previously reported sensitization thresholds. Even when applying significant assessment factors to the results from animal studies, the detected hydroperoxide levels appear too low to explain active sensitization. Thus the source and nature of the inducing agent responsible for the high number of positive patch tests reported to oxidized terpene fractions remains elusive.

\section{Conflict of interest disclosure}

All authors except M.N. and EGA are employees of fragrance companies using linalool and limonene in their products or the International Fragrance Association funded by the fragrance industry. M.N. works for a CRO providing the methods described in this study to third parties. EGA works at the University of Strasbourg, CNRS UMR 7177, and collected the samples from patients as a member of the Spanish Contact Dermatitis Group GEIDAC. 


\section{Acknowledgments and Funding Information}

The analytical work with GC-MS at SOLVIAS was funded by IDEA. The analysis by LC-MS was funded by the three participating laboratories (Firmenich, IFF and Givaudan). The study management was funded by IDEA. Manuscript writing was funded by Givaudan Schweiz AG. The synthesis of reference standards and sample collection was funded by the IDEA project.

We thankfully acknowledge all donors of samples, in particular the Spanish dermatological network collecting samples from patients (GEIDAC, Grupo Español de Investigación en Dermatitis Alérgica de Contacto).

Other members of the IDEA HP taskforce are gratefully acknowledged for fruitful discussions during various workshops. IDEA management team: Hans J. Bender; Industry scientists: Alain Chaintreau, Hugues Brévard and Neil Owen; Scientists from Academia: Jean-Marie Aubry, Anna Börje, Ann-Therese Karlberg, Ulrika Nilsson, David W. Roberts, and Véronique Rataj.

\section{Abbreviations:}

GC-MS, gas chromatography mass spectrometry; HP, hydroperoxide; HR-MS, high resolution mass spectrometry; LC-MS, liquid chromatography mass spectrometry; LC-CL, liquid chromatography coupled to chemiluminescence, LC-Q-ToF-MS; quadrupole time of flight mass spectrometer. LLNA, local lymph node assay; LOD, limit of detection; LOQ, limit of quantification 


\section{References}

1. Rastogi SC, Heydorn S, Johansen JD, Basketter DA. Fragrance chemicals in domestic and occupational products. Contact Dermatitis. 2001;45:221-225.

2. Letizia CS, Cocchiara J, Lalko J, Api AM. Fragrance material review on linalool. Food Chem Toxicol. 2003;41:943-964.

3. Roberts DW, Patlewicz G, Kern PS, et al. Mechanistic applicability domain classification of a local lymph node assay dataset for skin sensitization. Chemical Research in Toxicology. 2007;20:1019-1030.

4. Schnuch A, Uter W, Geier J, Lessmann H, Frosch PJ. Sensitization to 26 fragrances to be labelled according to current European regulation. Results of the IVDK and review of the literature. Contact Dermatitis. 2007;57:1-10.

5. Uter W, Geier J, Frosch P, Schnuch A. Contact allergy to fragrances: current patch test results (2005-2008) from the Information Network of Departments of Dermatology. Contact Dermatitis. 2010;63:254-261.

6. Hagvall L, Skold M, Brared-Christensson J, Borje A, Karlberg AT. Lavender oil lacks natural protection against autoxidation, forming strong contact allergens on air exposure. Contact Dermatitis. 2008;59:143-150.

7. Karlberg AT, Magnusson K, Nilsson U. Air oxidation of d-limonene (the citrus solvent) creates potent allergens. Contact Dermatitis. 1992;26:332-340.

8. Sköld M, Börje A, Harambasic E, Karlberg AT. Contact allergens formed on air exposure of linalool. Identification and quantification of primary and secondary oxidation products and the effect on skin sensitization. Chem Res Toxicol. 2004;17:1697-1705.

9. Hausen BM, Reichling J, Harkenthal M. Degradation products of monoterpenes are the sensitizing agents in tea tree oil. American Journal of Contact Dermatitis. 1999;10:68-77.

10. Hagvall L, Bäcktorp C, Svensson S, Nyman G, Börje A, Karlberg AT. Fragrance compound geraniol forms contact allergens on air exposure. Identification and quantification of oxidation products and effect on skin sensitization. Chem Res Toxicol. 2007;20:807-814.

11. Rudback J, Hagvall L, Borje A, Nilsson U, Karlberg AT. Characterization of skin sensitizers from autoxidized citronellol - impact of the terpene structure on the autoxidation process. Contact Dermatitis. 2014;70:329-339.

12. Sköld M, Börje A, Matura M, Karlberg AT. Studies on the autoxidation and sensitizing capacity of the fragrance chemical linalool, identifying a linalool hydroperoxide. Contact Dermatitis. 2002;46:267-272.

13. Christensson JB, Matura M, Gruvberger B, Bruze M, Karlberg AT. Linalool - a significant contact sensitizer after air exposure. Contact Dermatitis. 2010;62:32-41.

14. Nilsson U, Bergh M, Shao LP, Karlberg AT. Analysis of contact allergenic compounds in oxidized d-limonene. Chromatographia. 1996;42:199-205.

15. Karlberg AT, Shao LP, Nilsson U, Gafvert E, Nilsson JL. Hydroperoxides in oxidized d-limonene identified as potent contact allergens. Arch Dermatol Res. 1994;286:97-103.

16. Brared Christensson J, Andersen KE, Bruze M, et al. Air-oxidized linalool-a frequent cause of fragrance contact allergy. Contact Dermatitis. 2012;67:247-259.

17. Audrain $\mathrm{H}$, Kenward $\mathrm{C}$, Lovell $\mathrm{CR}$, et al. Allergy to oxidized limonene and linalool is frequent throughout the UK. British Journal of Dermatology. 2014;171:292-297.

18. Wlodek C, Penfold CM, Bourke JF, et al. Recommendation to test limonene hydroperoxides $0.3 \%$ and linalool hydroperoxides $1.0 \%$ in the British baseline patch test series. $\mathrm{Br} \mathrm{J}$ Dermatol. 2017;177:1708-1715.

19. Ung CY, White JML, White IR, Banerjee P, McFadden JP. Patch testing with the European baseline series fragrance markers: a 2016 update. Br J Dermatol. 2018;178:776-780.

20. Brared Christensson J, Andersen KE, Bruze M, et al. An international multicentre study on the allergenic activity of air-oxidized R-limonene. Contact Dermatitis. 2013;68:214-223.

21. Deza G, Garcia-Bravo B, Silvestre JF, et al. Contact sensitization to limonene and linalool hydroperoxides in Spain: a GEIDAC* prospective study. Contact Dermatitis. 2017;76:74-80.

22. Bennike $\mathrm{NH}$, Zachariae $\mathrm{C}$, Johansen JD. Non-mix fragrances are top sensitizers in consecutive dermatitis patients - a cross-sectional study of the 26 EU-labelled fragrance allergens. Contact Dermatitis. 2017;77:270-279. 
23. Brared Christensson J, Andersen KE, Bruze M, et al. Positive patch test reactions to oxidized limonene: exposure and relevance. Contact Dermatitis. 2014;71:264-272.

24. IDEA. International Dialogue for the Evaluation of Allergens. http://wwwideaprojectinfo; last accessed 22062016. 2016.

25. SCCS. Opinion on Fragrance allergens in cosmetic products. European Comission. 2012;SCCS/1459/11.

26. Kern S, Granier T, Dkhil H, Haupt T, Ellis G, Natsch A. Stability of limonene and monitoring of a hydroperoxide in fragranced products. Flavour Fragrance J. 2014;29:277-286.

27. Natsch A, Günthardt BF, Corbi E, et al. Interlaboratory evaluation of methods to quantify skin sensitizing hydroperoxides potentially formed from linalool and limonene in perfumes. Flavour Fragrance J. 2017.

28. Natsch A, Kern S, Corbi E, et al. Interlaboratory evaluation of methods to quantify skin-sensitizing hydroperoxides of limonene and linalool (II): Analysis in cosmetic bases. Flavour Fragrance J. 2018;33:322-330.

29. Calandra MJ, Impellizzeri J, Wang Y. An HPLC method for hydroperoxides derived from limonene and linalool in citrus oils, using post-column luminol-mediated chemiluminescence detection. Flavour Fragrance J. 2015;30:121-130.

30. Kern S, Dkhil H, Hendarsa P, Ellis G, Natsch A. Detection of potentially skin sensitizing hydroperoxides of linalool in fragranced products. Anal Bioanal Chem. 2014;406:6165-6178.

31. Rudbäck J, Islam MN, Börje A, Nilsson U, Karlberg AT. Essential oils can contain allergenic hydroperoxides at eliciting levels, regardless of handling and storage. Contact Dermatitis. 2015;73:253-254.

32. Ramzi A, Ahmadi H, Sadiktsis I, Nilsson U. A two-dimensional non-comprehensive reversed/normal phase high-performance liquid chromatography/tandem mass spectrometry system for determination of limonene and linalool hydroperoxides. J Chromatogr A. 2018.

33. Brared Christensson J, Hellsen S, Borje A, Karlberg AT. Limonene hydroperoxide analogues show specific patch test reactions. Contact Dermatitis. 2014. 
Table 1. Samples above reporting limit as per reduction method, re-analysed by different methods

\begin{tabular}{|c|c|c|c|c|c|c|c|}
\hline & & $\begin{array}{c}\text { Limonene-1- } \\
\text { OOH } \\
\end{array}$ & $\begin{array}{c}\text { Limonene- } \\
\text { 2-OOH }\end{array}$ & $\begin{array}{c}\text { Linalool- } \\
7-\mathrm{OOH} \\
\end{array}$ & $\begin{array}{c}\text { Linalool- } \\
\text { 6-OOH }\end{array}$ & Limonene & Linalı \\
\hline \multirow{5}{*}{$\begin{array}{l}\text { Sample A, Eau de } \\
\text { Toilette }\end{array}$} & GC-MS red. $(\mu \mathrm{g} / \mathrm{ml})$ & 91 & 36 & 25 & $<16$ & $>5000$ & 2600 \\
\hline & GC-MS red. (\% recovery) & $113 \%$ & $95 \%$ & $91 \%$ & $64 \%$ & & \\
\hline & LC-Orbitrap-MS $(\mu \mathrm{g} / \mathrm{ml})$ & 100 & n.r. & 18 & NF & & \\
\hline & LC-Q-ToF-MS ( $\mu \mathrm{g} / \mathrm{ml})$ & 77 & 19 & 40 & 25 & & \\
\hline & LC-CL $(\mu \mathrm{g} / \mathrm{ml})$ & 31.3 & 11.8 & 15 & 13.9 & & \\
\hline \multirow{5}{*}{$\begin{array}{c}\text { Sample A_new, Eau de } \\
\text { Toilette }\end{array}$} & GC-MS red. $(\mu \mathrm{g} / \mathrm{ml})$ & 45 & $<16$ & $<16$ & $<16$ & $>5000$ & 1600 \\
\hline & GC-MS red. (\% recovery) & $56 \%$ & $70 \%$ & $0 \%$ & $55 \%$ & & \\
\hline & LC-Orbitrap-MS $(\mu \mathrm{g} / \mathrm{ml})$ & 38.5 & n.r. & $\mathrm{NF}$ & $\mathrm{NF}$ & & \\
\hline & LC-Q-ToF-MS ( $\mu \mathrm{g} / \mathrm{ml})$ & 35 & $<5$ & $<5$ & $<5$ & & \\
\hline & LC-CL $(\mu \mathrm{g} / \mathrm{ml})$ & 8.3 & 2.2 & 0 & 0 & & \\
\hline \multirow{5}{*}{ Sample B, body oil } & GC-MS red. $(\mu \mathrm{g} / \mathrm{ml})$ & 36 & 69 & - & $<22$ & 710 & 860 \\
\hline & GC-MS red. (\% recovery) & $81 \%$ & $101 \%$ & $91 \%$ & $82 \%$ & & \\
\hline & LC-Orbitrap-MS $(\mu \mathrm{g} / \mathrm{ml})$ & NF & n.r. & $\mathrm{NF}$ & $\mathrm{NF}$ & & \\
\hline & LC-Q-ToF-MS $(\mu \mathrm{g} / \mathrm{ml})$ & 6 & $<5$ & 28 & 19 & & \\
\hline & $\mathrm{LC}-\mathrm{CL}(\mu \mathrm{g} / \mathrm{ml})$ & 5.7 & 0.5 & 11.1 & 10.5 & & \\
\hline \multirow{5}{*}{ Sample C, shower oil } & GC-MS red. $(\mu \mathrm{g} / \mathrm{ml})$ & 262 & 141 & 99 & 24 & 215000 & 1430( \\
\hline & GC-MS red. (\% recovery) & $74 \%$ & $84 \%$ & $83 \%$ & $108 \%$ & & \\
\hline & LC-Orbitrap-MS ( $\mu \mathrm{g} / \mathrm{ml})$ & NF & n.r. & NF & $\mathrm{NF}$ & & \\
\hline & LC-Q-ToF-MS ( $\mu \mathrm{g} / \mathrm{ml})$ & $<5$ & $<5$ & $<5$ & 15 & & \\
\hline & LC-CL $(\mu \mathrm{g} / \mathrm{ml})$ & 4.5 & 2.7 & 3.9 & 5.2 & & \\
\hline \multirow{5}{*}{ Sample D, body oil } & GC-MS red. $(\mu \mathrm{g} / \mathrm{ml})$ & $<22$ & $<22$ & $<22$ & 69 & 210 & 130( \\
\hline & GC-MS red. (\% recovery) & $94 \%$ & $80 \%$ & $100 \%$ & $109 \%$ & & \\
\hline & LC-Orbitrap-MS $(\mu \mathrm{g} / \mathrm{ml})$ & $\mathrm{NF}$ & n.r. & $\mathrm{NF}$ & $\mathrm{NF}$ & & \\
\hline & LC-Q-ToF-MS ( $\mu \mathrm{g} / \mathrm{ml})$ & $<5$ & $<5$ & $<5$ & $<5$ & & \\
\hline & $\mathrm{LC}-\mathrm{CL}(\mu \mathrm{g} / \mathrm{ml})$ & 0 & 0 & 0 & 0 & & \\
\hline \multirow{5}{*}{ Sample E, after shave ${ }^{1)}$} & GC-MS red. $(\mu \mathrm{g} / \mathrm{ml})$ & 18 & 20 & 72 & 81 & $>5000$ & 390( \\
\hline & GC-MS red. (\% recovery) & $92 \%$ & $97 \%$ & $114 \%$ & $102 \%$ & & \\
\hline & LC-Orbitrap-MS $(\mu \mathrm{g} / \mathrm{ml})$ & 7 & n.r. & ca. $5-10$ & $<25$ & & \\
\hline & LC-Q-ToF-MS $(\mu \mathrm{g} / \mathrm{ml})$ & 17 & $<5$ & 8 & 7 & & \\
\hline & $\mathrm{LC}-\mathrm{CL}(\mu \mathrm{g} / \mathrm{ml})$ & 1.6 & 1 & 2.8 & 4.6 & & \\
\hline
\end{tabular}

NF; not found

n.r.; Not reliable, the LC-Orbitrap-MS method is of limited reliability for limonene-2-OOH as reported before and experienced here again based on standard addition experiments.

1) Sample obtained from University of Stockholm ${ }^{32}$ and reported to contain $420 \mu \mathrm{g} / \mathrm{g}$ Linalool-6-OOH. 
Table 2. Samples from patch test positive patients analysed by different methods

\begin{tabular}{|c|c|c|c|c|c|}
\hline $\begin{array}{l}\text { Sample and history of } \\
\text { donating patient }\end{array}$ & Analytical methods & $\begin{array}{c}\text { Limonene- } \\
\text { 1-OOH }\end{array}$ & $\begin{array}{l}\text { Limonene- } \\
\text { 2-OOH }\end{array}$ & $\begin{array}{c}\text { Linalool-7- } \\
\text { OOH }\end{array}$ & $\begin{array}{c}\text { Linalool- } \\
\text { 6-OOH } \\
\end{array}$ \\
\hline \multirow{5}{*}{$\begin{array}{l}\text { O12, Body cream, Positive } \\
\text { some fragrances, Positive } \\
\text { Limonene ox }\end{array}$} & GC-MS red. $(\mu \mathrm{g} / \mathrm{ml})$ & $<22$ & $<22$ & $<22$ & $<22$ \\
\hline & GC-MS red. ( $\%$ recovery $)$ & $69 \%$ & $70 \%$ & $59 \%$ & $84 \%$ \\
\hline & LC-Orbitrap-MS $(\mu \mathrm{g} / \mathrm{ml})$ & $\mathrm{NF}$ & n.r. & $\mathrm{NF}$ & $\mathrm{NF}$ \\
\hline & LC-Q-ToF-MS $(\mu \mathrm{g} / \mathrm{ml})$ & $<5$ & n.r. & $<5$ & 11 \\
\hline & $\mathrm{LC}-\mathrm{CL}(\mu \mathrm{g} / \mathrm{ml})$ & $\mathrm{NF}$ & $\mathrm{NF}$ & $\mathrm{NF}$ & $\mathrm{NF}$ \\
\hline \multirow{5}{*}{$\begin{array}{l}\text { O13, Body cream, Positive } \\
\text { Linalool ox }\end{array}$} & GC-MS red. $(\mu \mathrm{g} / \mathrm{ml})$ & $<22$ & $<22$ & $<22$ & $<22$ \\
\hline & GC-MS red. ( $\%$ recovery) & $66 \%$ & $72 \%$ & $69 \%$ & $70 \%$ \\
\hline & LC-Orbitrap-MS $(\mu \mathrm{g} / \mathrm{ml})$ & $\mathrm{NF}$ & n.r. & NF & $\mathrm{NF}$ \\
\hline & LC-Q-ToF-MS $(\mu \mathrm{g} / \mathrm{ml})$ & $<5$ & $<5$ & $<5$ & 8 \\
\hline & LC-CL $(\mu \mathrm{g} / \mathrm{ml})$ & trace & trace & Trace & trace \\
\hline \multirow{5}{*}{$\begin{array}{l}\text { O14, Body wash, Positive } \\
\text { Linalool ox }\end{array}$} & GC-MS red. $(\mu \mathrm{g} / \mathrm{ml})$ & $<22$ & $<22$ & $<22$ & $<22$ \\
\hline & GC-MS red. (\% recovery) & $99 \%$ & $105 \%$ & $77 \%$ & $96 \%$ \\
\hline & LC-Orbitrap-MS $(\mu \mathrm{g} / \mathrm{ml})$ & $\mathrm{NF}$ & n.r. & $\mathrm{NF}$ & $\mathrm{NF}$ \\
\hline & LC-Q-ToF-MS $(\mu \mathrm{g} / \mathrm{ml})$ & $<5$ & $<5$ & $<5$ & $<5$ \\
\hline & $\mathrm{LC}-\mathrm{CL}(\mu \mathrm{g} / \mathrm{ml})$ & trace & trace & trace & trace \\
\hline \multirow{5}{*}{ O15, hand cream, Positive } & GC-MS red. $(\mu \mathrm{g} / \mathrm{ml})$ & $<22$ & $<22$ & $<22$ & $<22$ \\
\hline & GC-MS red. (\% recovery) & $80 \%$ & $109 \%$ & $118 \%$ & $118 \%$ \\
\hline & LC-Orbitrap-MS $(\mu \mathrm{g} / \mathrm{ml})$ & $\mathrm{NF}$ & n.r. & $\mathrm{NF}$ & $\mathrm{NF}$ \\
\hline & LC-Q-ToF-MS $(\mu \mathrm{g} / \mathrm{ml})$ & $<5$ & $<5$ & $<5$ & $<5$ \\
\hline & LC-CL $(\mu \mathrm{g} / \mathrm{ml})$ & $\mathrm{NF}$ & $\mathrm{NF}$ & $\mathrm{NF}$ & $\mathrm{NF}$ \\
\hline \multirow{5}{*}{ O17, shampoo, Positive } & GC-MS red. $(\mu \mathrm{g} / \mathrm{ml})$ & $<22$ & $<22$ & $<22$ & $<22$ \\
\hline & GC-MS red. (\% recovery) & $89 \%$ & $74 \%$ & $71 \%$ & $70 \%$ \\
\hline & LC-Orbitrap-MS $(\mu \mathrm{g} / \mathrm{ml})$ & $\mathrm{NF}$ & n.r. & $\mathrm{NF}$ & $\mathrm{NF}$ \\
\hline & LC-Q-ToF-MS $(\mu \mathrm{g} / \mathrm{ml})$ & $<5$ & $<5$ & $<5$ & $<5$ \\
\hline & LC-CL $(\mu \mathrm{g} / \mathrm{ml})$ & $\mathrm{NF}$ & $\mathrm{NF}$ & $\mathrm{NF}$ & $\mathrm{NF}$ \\
\hline \multirow{5}{*}{$\begin{array}{l}\text { O33, Body repair cream, } \\
\text { Positive }\end{array}$} & GC-MS red. $(\mu \mathrm{g} / \mathrm{ml})$ & $<22$ & $<22$ & $<22$ & $<22$ \\
\hline & GC-MS red. (\% recovery) & $51 \%$ & $55 \%$ & $53 \%$ & $58 \%$ \\
\hline & LC-Orbitrap-MS $(\mu \mathrm{g} / \mathrm{ml})$ & NF & n.r. & NF & NF \\
\hline & LC-Q-ToF-MS $(\mu \mathrm{g} / \mathrm{ml})$ & $<5$ & $<5$ & $<5$ & $<5$ \\
\hline & LC-CL $(\mu \mathrm{g} / \mathrm{ml})$ & $\mathrm{NF}$ & $\mathrm{NF}$ & $\mathrm{NF}$ & $\mathrm{NF}$ \\
\hline \multirow{5}{*}{$\begin{array}{l}\text { O34, skin repair cream, } \\
\text { Positive }\end{array}$} & GC-MS red. $(\mu \mathrm{g} / \mathrm{ml})$ & $<22$ & $<22$ & $<22$ & $<22$ \\
\hline & GC-MS red. ( $\%$ recovery) & $65 \%$ & $70 \%$ & $69 \%$ & $81 \%$ \\
\hline & LC-Orbitrap-MS $(\mu \mathrm{g} / \mathrm{ml})$ & $\mathrm{NF}$ & n.r. & NF & $\mathrm{NF}$ \\
\hline & LC-Q-ToF-MS $(\mu \mathrm{g} / \mathrm{ml})$ & $<5$ & $<5$ & $<5$ & $<5$ \\
\hline & $\mathrm{LC}-\mathrm{CL}(\mu \mathrm{g} / \mathrm{ml})$ & $\mathrm{NF}$ & $\mathrm{NF}$ & $\mathrm{NF}$ & $\mathrm{NF}$ \\
\hline \multirow{5}{*}{$\begin{array}{l}\text { O36, body milk, Positive } \\
\text { Linalool ox, Positive } \\
\text { Limonene ox }\end{array}$} & GC-MS red. $(\mu \mathrm{g} / \mathrm{ml})$ & $<22$ & $<22$ & $<22$ & $<22$ \\
\hline & GC-MS red. (\% recovery) & $73 \%$ & $76 \%$ & $76 \%$ & $85 \%$ \\
\hline & LC-Orbitrap-MS $(\mu \mathrm{g} / \mathrm{ml})$ & $\mathrm{NF}$ & n.r. & $\mathrm{NF}$ & $\mathrm{NF}$ \\
\hline & LC-Q-ToF-MS $(\mu \mathrm{g} / \mathrm{ml})$ & $<5$ & $<5$ & $<5$ & $<5$ \\
\hline & LC-CL $(\mu \mathrm{g} / \mathrm{ml})$ & NF & NF & NF & $\mathrm{NF}$ \\
\hline
\end{tabular}


O37, Bubble bath, Positive

Limonene ox Unsure

Linalool ox, recommended

to be retested

O40, shampoo, Positive
Linalool ox

O41, body cream, Unsure

Linalool ox, recommended

to be retested

\begin{tabular}{|l|c|c|c|c|} 
GC-MS red. $(\mu \mathrm{g} / \mathrm{ml})$ & $<22$ & $<22$ & $<22$ & $<22$ \\
\hline GC-MS red. $(\% \mathrm{recovery})$ & $93 \%$ & $94 \%$ & $79 \%$ & $89 \%$ \\
\hline LC-Orbitrap-MS $(\mu \mathrm{g} / \mathrm{ml})$ & $\mathrm{NF}$ & $\mathrm{n.r.}$ & $\mathrm{NF}$ & $\mathrm{NF}$ \\
\hline LC-Q-ToF-MS $(\mu \mathrm{g} / \mathrm{ml})$ & $<5$ & $<5$ & $<5$ & $<5$ \\
\hline LC-CL $(\mu \mathrm{g} / \mathrm{ml})$ & $\mathrm{NF}$ & $\mathrm{NF}$ & $\mathrm{NF}$ & $\mathrm{NF}$ \\
\hline GC-MS red. $(\mu \mathrm{g} / \mathrm{ml})$ & $<22$ & $<22$ & $<22$ & $<22$ \\
\hline GC-MS red. $(\% \mathrm{recovery})$ & $97 \%$ & $96 \%$ & $90 \%$ & $96 \%$ \\
\hline LC-Orbitrap-MS $(\mu \mathrm{g} / \mathrm{ml})$ & $\mathrm{NF}$ & $\mathrm{n.r}$. & $\mathrm{NF}$ & $\mathrm{NF}$ \\
\hline LC-Q-ToF-MS $(\mu \mathrm{g} / \mathrm{ml})$ & $<5$ & $<5$ & $<5$ & $<5$ \\
\hline LC-CL $(\mu \mathrm{g} / \mathrm{ml})$ & $\mathrm{NF}$ & $\mathrm{NF}$ & $\mathrm{NF}$ & $\mathrm{NF}$ \\
\hline GC-MS red. $(\mu \mathrm{g} / \mathrm{ml})$ & $<22$ & $<22$ & $<22$ & $<22$ \\
\hline GC-MS red. $(\% \mathrm{recovery})$ & $97 \%$ & $96 \%$ & $90 \%$ & $96 \%$ \\
\hline LC-Orbitrap-MS $(\mu \mathrm{g} / \mathrm{ml})$ & $\mathrm{NF}$ & $\mathrm{n} . \mathrm{r}$. & $\mathrm{NF}$ & $\mathrm{NF}$ \\
\hline LC-Q-ToF-MS $(\mu \mathrm{g} / \mathrm{ml})$ & $<5$ & $<5$ & $<5$ & $<5$ \\
\hline LC-CL $(\mu \mathrm{g} / \mathrm{ml})$ & $\mathrm{NF}$ & $\mathrm{NF}$ & $\mathrm{NF}$ & $\mathrm{NF}$ \\
\hline
\end{tabular}

NF; not found

n.r.; Not reliable

Note: This Table could also be left within supporting information

Table 3. Two commercial fine fragrance samples with defined storage history analysed by the GC-MS-reduction method

\begin{tabular}{|c|c|c|c|c|c|c|}
\hline Condition & $\begin{array}{c}\text { Limonene- } \\
1-00 H\end{array}$ & $\begin{array}{c}\text { Limonene- } \\
\text { 2-OOH }\end{array}$ & $\begin{array}{c}\text { Linalool- } \\
\text { 7-OOH }\end{array}$ & $\begin{array}{c}\text { Linalool- } \\
\text { 6-OOH }\end{array}$ & Limonene & Linalool \\
\hline Perfume 1 , fresh & 16 & 33 & 18 & $<16$ & 4100 & 2200 \\
\hline Perfume 1,3 years at RT & $<16$ & $<16$ & $<16$ & $<16$ & 4200 & 2300 \\
\hline Perfume 1,3 months, $45^{\circ} \mathrm{C}$ & $<16$ & 18 & $<16$ & $<16$ & 4300 & 2300 \\
\hline Perfume 2, fresh & 18 & 18 & 36 & $<16$ & $>5000$ & 4200 \\
\hline Perfume 2,6 years at RT & 19 & $<16$ & 32 & $<16$ & $>5000$ & 4100 \\
\hline Perfume 2,3 months, $45^{\circ} \mathrm{C}$ & 24 & $<16$ & 30 & $<16$ & $>5000$ & 3900 \\
\hline
\end{tabular}


Dose of

hydroperoxide in test

Dose per area

preparation

LLNA Dose inducing sensitisation (EC3)

$3300 \mu \mathrm{g} / \mathrm{g}(0.33 \%)$

$82.5 \mu \mathrm{g} / \mathrm{cm}$

Patch test limonene-HP ${ }^{1)}$, routine diagnostic level

$3300 \mu \mathrm{g} / \mathrm{g}(0.33 \%)$

$156 \mu \mathrm{g} / \mathrm{cm}^{2}$

Patch test limonene-1-OOH ${ }^{2)}$, diagnostic level

$5000 \mu \mathrm{g} / \mathrm{g}(0.5 \%)$

$228 \mu \mathrm{g} / \mathrm{cm}^{2}$

Defined reporting limit

$50 \mu \mathrm{g} / \mathrm{g}$

$0.1-0.5^{3)} \mu \mathrm{g} / \mathrm{cm}^{2}$

Analytical data market surveillance: (Max. value

$90 \mu \mathrm{g} / \mathrm{g}(0.009 \%)$

$0.2 \mu \mathrm{g} / \mathrm{cm}^{2}{ }^{4}$

of $\mathrm{n}=104)$

${ }^{1)}$ Mixture of isomers, not specifically 1-OOH-isomer

${ }^{2)}$ Dose used in study on specific Limonene-1-OOH isomer by Christensson ${ }^{33}$

${ }^{3)}$ Different dose depending on product type (Cream $10 \mathrm{mg} / \mathrm{cm}^{2}$ higher than fine fragrance, $2.2 \mathrm{mg} / \mathrm{cm}^{2}$ )

${ }^{4)}$ Based on the typical application dose of fine fragrance per area $\left(2.2 \mathrm{mg} / \mathrm{cm}^{2}\right)$

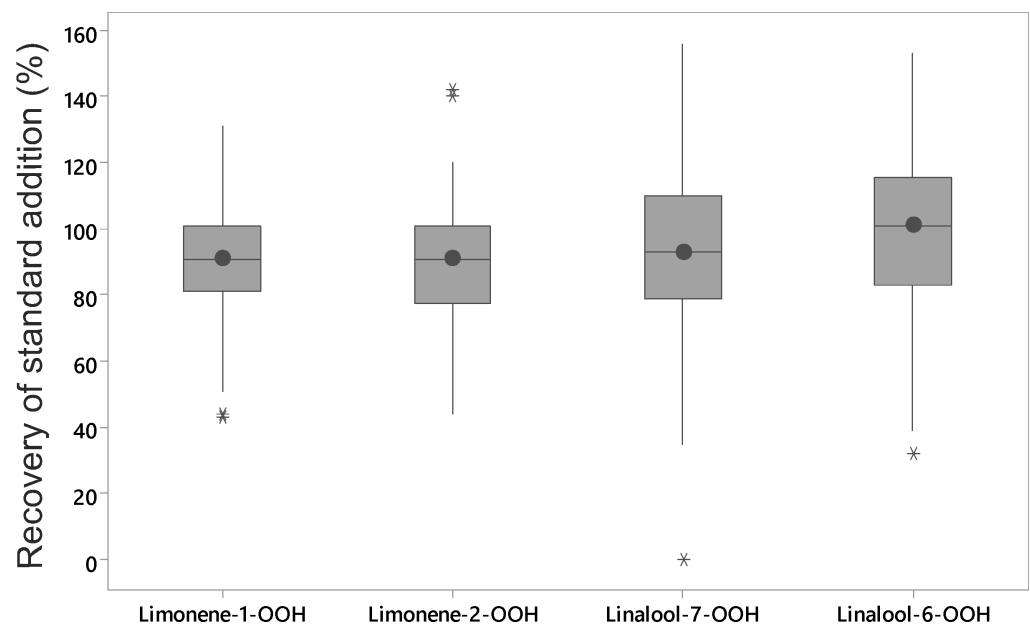

Figure 1. Recovery of standard addition $(50 \mu \mathrm{g} / \mathrm{g})$ of four HP added to 104 products analysed by the GC-MS-reduction method. 